\title{
A comparative clinicopathological study between ultrasonography, mammography, FNAC and core needle biopsy of breast lump
}

\author{
Arnab Mandal \\ Department of General surgery,BSMCH,West Bengal,India.PIN-722102 \\ Pradipta Jana ( $\sigma$ dr.pradipta.jana@gmail.com ) \\ BSMCH,West Bengal,India \\ Sabyasachi Bakshi \\ Department of General surgery,BSMCH,West Bengal,India.PIN-722102

\section{Ram Krishna Mandal} \\ Department of General surgery,BSMCH,West Bengal,India.PIN-722102
}

\section{Research Article}

Keywords: Breast Lump, ultrasonography, mammography, FNAC, core needle biopsy

Posted Date: May 20th, 2020

DOI: https://doi.org/10.21203/rs.3.rs-28882/v1

License: (a) (i) This work is licensed under a Creative Commons Attribution 4.0 International License. Read Full License 


\section{Abstract}

\section{BACKGROUND:}

Early presentation and prompt diagnosis is the essential key in treatment of different variety of neoplastic as well as nonneoplastic breast disease. In this study usefulness of HRUSG, Mammography, FNAC and Core Needle Biopsy in correlation with histopathological pattern, was assessed.

\section{METHODS:}

After matching the criteria, 212 cases, were taken for this prospective, single center, observational study.

\section{RESULTS:}

Out of 212 cases, $163(76.88 \% \%)$ were benign lesions, $49(23.11 \%)$ were malignant and $1(0.47 \%)$ were of inflammatory pathology. Benign to malignant breast disease ratio was 3.3:1. Out of 49 malignant cases, $45(91.83 \%)$ were ductal cell carcinoma and 4 (8.16\%) was apocrine carcinoma. Maximum numbers of cancer patients were found in the 51- 60 year age groups.The sensitivity, specificity, Positive predictive value and Negative Predictive value of mammography in detecting carcinoma breast were $87.76 \%, 64.71 \%, 87.76 \%$ and $64.71 \%$ respectively. The sensitivity, specificity, PPV and NPV of HRUSG in detecting carcinoma breast were $85.71 \%, 90.18 \%, 72.41 \%$ and $95.45 \%$ respectively.Among benign lesions, 47 (28.83) \% were diagnosed by mammography and 147(90.18) \% were diagnosed by HRUSG. When these modalities were combined, $>95 \%$ of the lesions was diagnosed accurately.

\section{CONCLUSIONS:}

Ultra sound used liberally as an adjunct to mammography, increase the cancer detection rate. Core needle biopsy is found more accurate but FNAC have limited value in evaluation of benign breast lump. This study also proves that preoperative categorization of breast lesions is utmost important for management of the patient and this will help to avoid unnecessary surgical treatment.

\section{Introduction}

Breast lump is a very common problem among females attending surgical outpatient department. Breast is a dynamic structure which changes throughout reproductive life, and the cyclical changes during menstrual period are also added with it. About $30 \%$ of women suffer from breast disease in their lifetime ${ }^{1}$. The pathogenesis involves disturbance in the breast physiology extending from an extreme normalcy to well defined disease processes. Approximately $40 \%$ of all patients with breast problems present with a benign breast lump, and often unnecessary surgeries are performed for benign diseases. Benign breast lumps are the most common lesions accounting for about 60 to $80 \%$ of all the breastdisease ${ }^{2}$. ANDI (Aberrations of Normal Development and Involution) is a group of benign breast disorder, commonly presents with discrete lump in the breast which may be bilateral but commonly found in the upper outer quadrant. These group includes cyclical nodularity and mastalgia, cysts, fibroadenoma, duct ectasia and periductal mastitis ${ }^{3}$. Studies have shown that there is a relationship between benign breast disease and breast cancer. Risk of cancer varies according to the histological grading of benign breast disease $e^{4,5,6}$.

There are various modalities for evaluation of breast lump such as high resolution ultrasonography (HRUSG), mammography, FNAC, core needle biopsy, but they have varied sensitivity ${ }^{5,7}$. Clinical evaluation, followed by HRUSG \& Mammography are simple method to detect causes as these are inexpensive and non-invasive.These methods are very effective in resource poor areas.

Malignant neoplasm is more frequent in old females like other cancerous conditions. Delay in diagnosis causes management more complicated, as most of them usually present in advanced stage. Mammography is very useful investigation to detect breast carcinoma as well. Chances of missing carcinoma persist in few cases with HRUSG. There is lack of structured breast screening programs in most of the resource poor areas. Traditional belief, lack of awareness, poor socioeconomic conditions is 
also contributing in late detection of cases. A test therefore should provide a degree of diagnostic accuracy so that unnecessary biopsy can be prevented. Breast cancer can be diagnosed with thorough clinical examination and diagnostic aid such as HRUSG, Mammography, and Core needle biopsy ${ }^{7}$. Strategy in managing breast lump is to decide whether the lump is due to normal variation or it is an abnormality. If the lump is found abnormal, then it is to be determined whether malignant or not. Preoperative diagnosis using a combination of clinical examination, high resolution ultrasonography, mammography and either biopsy (using a wide bone cutting needle) or aspiration cytology (using a narrow hypodermic needle in resource poor areas) is commonly used.

The purpose of the present study study was to categorize breast lumps, to find out mode of presentation and demographic pattern if breast lump in female patients and to compare between different diagnostic modality like HRUSG vs. Mammography and Fine Needle Aspiration Cytology vs. Tissue Biopsy with respect to histopathology findings.

\section{Methods}

This is an institution based (single center) prospective, observational hospital based, comparative, cross sectional study. The study population comprised of 212 cases of breast masses (who attended OPD from March 2018 to August 2019 in general surgery department of BSMCH medical college). This study was divided into two parts: 1. prospective-patients presenting in OPD and 2. Retrospective-analysis of the patients of breast lump from the preceding 18 months at BSMCH. Here, detailed history, clinical examination and biopsy of the breast lump were carried out. The subjects satisfied the inclusion and exclusion criteria mentioned below. The primary data for this study were the investigation reports of the subjects.

\section{INCLUSION CRITERIA:}

All female patients attending surgery outpatient department with complaint of clinically palpable breast lump (solitary/multiple and unilateral/bilateral) irrespective of age, socioeconomic status, duration were included.

\section{EXCLUSION CRITERIA:}

Patients who refused to give consent. Male and pregnant female patients excluded from the study. Some patients did not followed up, hence they were excluded from the study. Patients with acute and tender breast lump like breast abscess were also excluded.

In outpatient department a detailed history and thorough physical examination of the presenting palpable breast lump has been carried out and data was saved. All the subjects were then undergone HRUSG and mammographic scanning.The subjects with suspicion of malignancy were undergone FNAC and core needle biopsy. The lumps were then excised (in case of benign lesion) or proper oncological surgery were done in malignant cases.Post operatively all specimens were sent for histopathological examination.All the statistical analysis was carried out using available standard statistical software. Odds ratio with $95 \%$ confidence interval $(\mathrm{Cl})$ and multivariate analysis has used establish the interrelationships between pre-operative and intra operative findings. All statistical tests has two tailed and $P$ value $<0.05$ has taken as significant.

\section{Results}

In the present study, majority of the patients $64(30.2 \%)$ belongs to the 21-30 Year age group, the next highest numbers of patients being in the $31-40$ Year age group stood at 49 (23.1\%). Of the various conditions diagnosed, most of the fibroadenoma belongs to the $<20$ year category being 32 (37.20\% of total number of fibroadenoma), most of the fibroadenosis belongs to the $21-30$ Years of categories (50\%).

\section{TABLE - 1: Age wise distribution of different breast lumps}

The most common lesion was fibroadenoma 86 (40.56\%), followed by fibroadenosis including other benign breast lump followed by malignant tumor $49(23.11 \%)$ in that order. 


\begin{tabular}{|c|c|c|c|c|c|c|c|}
\hline \multirow{2}{*}{$\begin{array}{c}\text { CLINICAL } \\
\text { DIAGNOSIS }\end{array}$} & \multicolumn{6}{|c|}{ AGE(YEARS) } & \multirow[t]{2}{*}{ TOTAL } \\
\hline & $<20$ & $21-30$ & $31-40$ & $41-50$ & $51-60$ & $>60$ & \\
\hline FIBROADENOMA & 32 & 31 & 14 & 6 & 3 & & $86(40.56 \%)$ \\
\hline FIBROADENOSIS & 1 & 8 & 4 & 3 & & & $16(7.54 \%)$ \\
\hline $\begin{array}{c}\text { FIBROCYSTIC } \\
\text { MASS }\end{array}$ & 2 & 13 & 15 & 6 & & 1 & $37(17.45 \%)$ \\
\hline PHYLLOIDS & & 4 & 4 & 1 & & & $9(4.24 \%)$ \\
\hline OTHERS & 2 & 5 & 6 & 1 & & 1 & $15(7.07 \%)$ \\
\hline MALIGNANT & 1 & 3 & 6 & 18 & 16 & 5 & $49(23.11 \%)$ \\
\hline TOTAL & $38(17.9 \%)$ & $64(30.2 \%)$ & $49(23.1 \%)$ & $35(16.5 \%)$ & $19(8.96 \%)$ & $7(3.30 \%)$ & 212 \\
\hline
\end{tabular}

TABLE - 2: HISTOPATHOLOGICAL FINDINGS

\begin{tabular}{|c|c|}
\hline NATURE OF THE TUMOUR & Number of Subjects \\
\hline BENIGN & 163 \\
\hline MALIGNANT & 49 \\
\hline TOTAL & 212 \\
\hline
\end{tabular}

TABLE - 3: HISTOLOGICAL CORRELATION IN PATIENTS CYTOLOGICALLY DIAGNOSED AS BENIGN \& MALIGNANT DISEASE

\begin{tabular}{|c|c|c|c|c|}
\hline \multirow[t]{2}{*}{$\begin{array}{l}\text { Types as diagnosed } \\
\text { histologically }\end{array}$} & \multirow[t]{2}{*}{$\begin{array}{l}\text { Total No. of } \\
\text { Cases }\end{array}$} & \multirow[t]{2}{*}{$\begin{array}{l}\text { No. of cases tissue } \\
\text { received }\end{array}$} & \multicolumn{2}{|l|}{$\begin{array}{c}\text { Histopathological } \\
\text { correlation }\end{array}$} \\
\hline & & & Consistent & $\begin{array}{c}\text { In } \\
\text { consistent }\end{array}$ \\
\hline Fibroadenoma & 86 & 86 & $81(94.18 \%)$ & $5(5.81 \%)$ \\
\hline Fibrocystic ds & 37 & 37 & $31(83.78 \%)$ & $6(16.21 \%)$ \\
\hline Fibroadenosis & 16 & 15 & $15(100 \%)$ & \\
\hline Phylloids Tumor & 9 & 9 & $7(77.77 \%)$ & $2(2.22 \%)$ \\
\hline Tuberculosis & 1 & 1 & $1(100 \%)$ & \\
\hline Other & 14 & 14 & $3(21.42 \%)$ & $11(78.57 \%)$ \\
\hline Total (Benign) & 163 & 162 & 138(85.18\%) & $24(14.81 \%)$ \\
\hline Ductal Carcinoma & 44 & 44 & $43(97.72 \%)$ & $1(2.27 \%)$ \\
\hline Lobular Carcinoma & 2 & 2 & $2(100 \%)$ & \\
\hline Papillary Carcinoma & 2 & 2 & & $2(100 \%)$ \\
\hline $\begin{array}{l}\text { Mucin secreting } \\
\text { Carcinoma }\end{array}$ & 1 & 1 & & $1(100 \%)$ \\
\hline Total (Malignant) & 49 & 49 & $45(91.83 \%)$ & $4(8.16 \%)$ \\
\hline
\end{tabular}

In this study, sensitivity \& specificity of clinical breast examination for detection of malignancy is found to be $93.87 \%$ \& $96.44 \%$ respectively.

TABLE-4: MAMMOGRAPHIC DIAGNOSIS OF DIFFERENT BREAST LUMP 


\begin{tabular}{|c|c|c|c|}
\hline \multirow[b]{2}{*}{ MAMMOGRAPHICAL DIAGNOSIS } & \multicolumn{3}{|c|}{ PALPABLE TUMOUR $(\mathrm{n}=212)$} \\
\hline & $\begin{array}{c}\text { BIRADS } \\
\text { SCORING }\end{array}$ & $\mathrm{NO}$ & PERCENT \\
\hline INCONCLUSIVE, more towards BENIGN & 0,1 & 104 & $49.05 \%$ \\
\hline BENIGN & 2 & 47 & $22.16 \%$ \\
\hline SIGNIFICANT, more towards MALIGNANT & $3 \& 4$ & 19 & $8.96 \%$ \\
\hline MALIGNANT & $5 \& 6$ & 42 & $19.81 \%$ \\
\hline TOTAL & & 212 & $100 \%$ \\
\hline
\end{tabular}

TABLE- 5: ANALYSIS OF MAMMOGRAPHIC DATA IN BENIGN AND MALIGNANT DISEASE

\begin{tabular}{|c|c|c|c|}
\hline \multicolumn{2}{|c|}{} & \multicolumn{1}{l}{ HPE } & DIAGNOSIS \\
\cline { 3 - 4 } & MALIGNANCY & DISEASE & NOT DISEASED \\
\hline MAMMOGRAPHY & DISEASE & 43 & 6 \\
\cline { 2 - 4 } DIAGNOSIS & NOT DISEASED & 6 & 11 \\
\hline
\end{tabular}

\begin{tabular}{|c|c|c|}
\hline MAMMOGRAPHIC & BENIGN DISEASE & $(\mathbf{n}=\mathbf{1 6 3})$ \\
\cline { 2 - 3 } FINDINGS & NO & PERCENTAGE \\
\hline DETECTED & 47 & $28.83 \%$ \\
\hline NOT DETECTED & 116 & $71.16 \%$ \\
\hline TOTAL & 163 & $100 \%$ \\
\hline
\end{tabular}

(71.16\%) most of which are under 35 years of age.

Mammography can detect only 47 cases $(28.83 \%)$ cases \& not able to detect accurately 116 cases

TABLE- 6: VALIDITY OF MAMMOGRAPHY

\begin{tabular}{|c|c|c|c|c|c|c|c|}
\hline $\begin{array}{c}\text { SL. } \\
\text { NO. }\end{array}$ & SOURCE & $\begin{array}{c}\text { TOTAL } \\
\text { PATIENTS }\end{array}$ & $\begin{array}{c}\text { NO. OF CA } \\
\text { PATIENTS }\end{array}$ & SENSITIVITY & SPECIFICITY & PPV & NPV \\
\hline 1 & $\begin{array}{c}\text { Tan K.P. et al. } \\
2014^{8}\end{array}$ & 326 & 74 & $49 \%$ & $89 \%$ & $53 \%$ & $88 \%$ \\
\hline 2 & $\begin{array}{c}\text { P. K. Tewari, } \\
2017^{9}\end{array}$ & 53 & 10 & $77.77 \%$ & $97.72 \%$ & $87.5 \%$ & $95.55 \%$ \\
\hline 3 & $\begin{array}{c}\text { Ann L. Brown et. } \\
\text { al. 2017 }\end{array}$ & 568 & 77 & $85.7 \%$ & $91.4 \%$ & $47.1 \%$ & $98.6 \%$ \\
\hline 4 & $\begin{array}{c}\text { Thomas M. Kolb } \\
\text { et. al. 2002 }\end{array}$ & 11130 & 221 & $77.6 \%$ & $98.8 \%$ & $35.8 \%$ & $99.8 \%$ \\
\hline 5 & $\begin{array}{c}\text { WT Yang et al } \\
1996^{12}\end{array}$ & 480 & 480 & $92 \%$ & $94 \%$ & $84 \%$ & \\
\hline 6 & $\begin{array}{c}\text { This study 2018- } \\
2019\end{array}$ & 212 & 49 & $87.76 \%$ & $64.71 \%$ & $87.76 \%$ & $64.71 \%$ \\
\hline
\end{tabular}

TABLE - 7: USG FINDING IN DIFFERENT BREAST LUMP 


\begin{tabular}{|c|c|c|c|c|c|c|}
\hline \multicolumn{2}{|c|}{ HRUSG FEATURES } & TOTAL & \multicolumn{2}{|c|}{ PALPALE TUMOURS } & \multicolumn{2}{c|}{ (N=212) } \\
\cline { 3 - 7 } & & BENIGN & $\%$ & MALIGNANT & $\%$ \\
\hline \multirow{2}{*}{ SHAPE } & $\begin{array}{c}\text { ROUND/ } \\
\text { OVAL }\end{array}$ & 155 & 148 & 90.79 & 7 & 14.28 \\
\cline { 2 - 7 } & $\begin{array}{c}\text { LOB/ } \\
\text { IRREGULAR }\end{array}$ & 56 & 14 & $\mathbf{8 . 5 8}$ & 42 & $\mathbf{8 5 . 7 1}$ \\
\hline \multirow{2}{*}{ DEFINE } & WELL DEFINED & $\mathbf{1 5 0}$ & 145 & $\mathbf{8 8 . 9 5}$ & 5 & 10.20 \\
\cline { 2 - 8 } & ILL DEFINED & $\mathbf{4 0}$ & 17 & 10.42 & 44 & $\mathbf{8 9 . 7 9}$ \\
\hline VASCULARITY & NORMAL & $\mathbf{7 7}$ & 150 & $\mathbf{9 2 . 0 2}$ & 26 & 53.06 \\
\cline { 2 - 8 } & INCREASED & $\mathbf{1 5}$ & 12 & $\mathbf{7 . 3 6}$ & 23 & $\mathbf{4 6 . 9 3}$ \\
\hline
\end{tabular}

TABLE - 8: VALIDITY OF USG

\begin{tabular}{|c|c|c|c|c|c|c|c|}
\hline $\begin{array}{c}\text { Sl. } \\
\text { No. }\end{array}$ & Source & $\begin{array}{c}\text { No. of } \\
\text { Patients }\end{array}$ & $\begin{array}{c}\text { No. of Cancer } \\
\text { Patients }\end{array}$ & Sensitivity & Specificity & PPV & NPV \\
\hline 1. & Tan K.P. et. al. 2014 & 326 & 74 & $82 \%$ & $84 \%$ & $60 \%$ & $94 \%$ \\
\hline 2. & $\begin{array}{c}\text { Dar. Ren. Chen. et. al } \\
2000^{13}\end{array}$ & 243 & 82 & $97.6 \%$ & $79.5 \%$ & $70.8 \%$ & $98.5 \%$ \\
\hline 3. & $\begin{array}{c}\text { P. K. Tewari et. al. } \\
2017^{9}\end{array}$ & 53 & 10 & $55.55 \%$ & $97.72 \%$ & $83.33 \%$ & $91.48 \%$ \\
\hline 4. & $\begin{array}{c}\text { Lingaraju et. al. } \\
2016^{14}\end{array}$ & 80 & 14 & $85.8 \%$ & $96.4 \%$ & $66.7 \%$ & $100 \%$ \\
\hline 5. & $\begin{array}{c}\text { Thomas M. Kolb et. } \\
\text { al. 2002 }\end{array}$ & 11130 & 221 & $75.3 \%$ & $96.8 \%$ & $20.5 \%$ & $99.7 \%$ \\
\hline 6. & $\begin{array}{c}\text { This Study 2018- } \\
2019\end{array}$ & 212 & 49 & $85.71 \%$ & $90.18 \%$ & $72.41 \%$ & $95.45 \%$ \\
\hline
\end{tabular}

Ultrasound has an established role in assessing breast abnormality as an adjunct to mammography in older women and is a first line investigation in young women with mammographically dense breast. Some malignant breast lesion are not visible on mammography but are detected by high resolution ultrasound. The use of high resolution ultrasound in addition to clinical examination and mammography may result in an increased rate of breast cancer detection. The study was undertaken to calculate the predictive value of high resolution ultrasonography in patients presenting with breast lumps. The sensitivity, specificity, positive and negative predictive values were comparable to the data obtained by different studies conducted elsewhere. HRUSG is more specific in diagnosis of lumps in younger females ( $<35 \mathrm{yrs}$ ), due to dense breast tissue.

TABLE - 9: VALIDITY OF FNAC

\begin{tabular}{|c|c|c|c|c|c|c|c|}
\hline $\begin{array}{c}\text { Sl. } \\
\text { No. }\end{array}$ & Source & $\begin{array}{c}\text { No. Of } \\
\text { Patients }\end{array}$ & $\begin{array}{c}\text { No. Of CA } \\
\text { Patients }\end{array}$ & Sensitivity & Specificity & PPV & NPV \\
\hline 1. & Abhijit Saha et. al.2016 & 50 & 50 & $69 \%$ & $100 \%$ & $100 \%$ & $38.1 \%$ \\
\hline 2. & S. Giri et. al. 2013 & 277 & 12 & $90.32 \%$ & $100 \%$ & $100 \%$ & $86.36 \%$ \\
\hline 3. & Ligaraju et. al. 2016 214 & 80 & 14 & $98.5 \%$ & $97.1 \%$ & $73.3 \%$ & $100 \%$ \\
\hline 4. & Ying- Hua et. al. 2012 & 14 & 46 & $92.7 \%$ & $92.1 \%$ & & \\
\hline 5. & $\begin{array}{c}\text { Bettina H. Kamphausen } \\
\text { et. al. 2003 } 18\end{array}$ & 354 & 354 & $90 \%$ & $100 \%$ & $100 \%$ & $90 \%$ \\
\hline 6. & This Study 2018-2019 & 212 & 49 & $93.88 \%$ & $96.32 \%$ & $88.46 \%$ & $98.12 \%$ \\
\hline
\end{tabular}


In comparative analysis of FNAC and histopathology diagnosis, we observed 9 cases of cytologically interpreted errors; which were 6 cases of false positive and 3 false negative cases. One false negative case diagnosed as BPPD with atypia turn out to be malignant cases (Mucus secreting CA of breast). In 2 false positive cases; one was multiple solid palillomas with area of adenosis \& one case was benign fibrous histiocytoma. FNAC of breast lesion is sensitive, specific, \& highly accurate as the initial investigation of palpable breast lesions in this hospital.

TABLE - 10: VALIDITY OF CORE NEEDLE BIOPSY

\begin{tabular}{|c|c|c|c|c|c|c|c|}
\hline $\begin{array}{c}\text { Sl. } \\
\text { No. }\end{array}$ & Source & $\begin{array}{c}\text { No. of } \\
\text { Patients }\end{array}$ & $\begin{array}{c}\text { No. of CA } \\
\text { Patients }\end{array}$ & Sensitivity & Specificity & PPV & NPV \\
\hline 1. & $\begin{array}{c}\text { Abhijit Saha et. } \\
\text { al.2016 }\end{array}$ & 50 & 50 & $88.3 \%$ & $100 \%$ & $53.3 \%$ & $100 \%$ \\
\hline 2. & $\begin{array}{c}\text { Rebekah R. White et. al. } \\
2000^{19}\end{array}$ & 1042 & 240 & $97 \%$ & $94 \%$ & $88 \%$ & $98 \%$ \\
\hline 3. & $\begin{array}{c}\text { Michael S. Ballo 1996 } \\
\text { A.S. Fattahi et. al. } \\
2016^{21}\end{array}$ & 124 & 124 & $90 \%$ & $100 \%$ & & \\
\hline 4. & $\begin{array}{c}\text { A. } \\
\text { 20 }\end{array}$ & 116 & $92.6 \%$ & $100 \%$ & $100 \%$ & $91.8 \%$ \\
\hline 5. & S Hari et al.2016 22 & 36 & 30 & $46.7 \%$ & $100 \%$ & $100 \%$ & $27.3 \%$ \\
\hline 6 & This Study 2018-2019 & 212 & 49 & $97.96 \%$ & $98.77 \%$ & $96 \%$ & $99.38 \%$ \\
\hline
\end{tabular}

In comparative analysis of core needle biopsy report and histopathology diagnosis, we observed 3 cases of cytologically interpreted errors which were 2 cases of false positive and 1 case of false negative cases. 1 False negative case diagnosed as BPPD with atypia turn out to be malignant cases (Mucus secreting CA of breast). In 2 false positive cases were multiple solid papillomas with area of adenosis. Core needle biopsy of breast lesion is sensitive, specific, \& highly accurate as the final investigation of palpable breast lesions in this hospital.

\section{Discussion}

In the present study, most of the patients belongs to the active reproductive Year (20-40 years) depicting the occurrence of aberrations as depicted in literature, in the most active years. At the same time, there are patients presented with breast carcinoma in postmenopausal age group.

Fibroadenoma was the most common breast lesion in our study as well as in reports elsewhere from India. ${ }^{23,24}$

Most fibroadenomas occurring at a slightly earlier age group than fibroadenosis depicts the fact that fibrocystic changes are variants of the repeated cyclical changes in the form of menstruation, pregnancy and lactation. A higher incidence of fibroadenoma and a lesser frequency of fibrocystic disease in Indian women have been explained on the basis of early menarche, early marriage, and multi parity. Most of the breast cyst belonging to the $30-40$ age groups in this study and is described as an evolutional changes.

Most common presentation of breast lumps in female patient was a painful lump (52\%), followed by painless lump. Pattern of pain is very commonly non cyclical (81\%). The side of breast involved shows no significant difference between left (46) and right (42).Bilateral involvement is only seen in $12 \%$ of the cases.

Though pain in the breast lump is the commonest symptoms, systemic symptoms like fever, wound with discharge, redness and pain in opposite breast are also seen.

As obvious in most of these studies the most of the breast lump was firm in consistency (74\%) and mobile (64\%).

The total 212 of female patients were studied, out of which (74\%) had benign lesion and (26\%) had malignant lesions. 
The highest incidences of breast lumps in our study were in the age group of 21 - $30 \mathrm{yrs}$. The least incidence of breast lesions was in the age group of 11-20 yrs. The maximum numbers of benign breast lesions are in the age group of 21-40years and maximum number of malignant lesions was seen in the age group above 50 years (50\%).An increasing numbers of patients are in the 20 to 40 years of age, and this definitely is a very disturbing trend. In India, the average age of developing a breast cancer has undergone a significant shift over last few decades.

In the present study, menstrual irregularity is seen in a few cases, whether his carries any significance is inconclusive. Most of the malignant cases were seen in postmenopausal age group.

Least half the cases of breast lump have been treated conservatively (9\%). Rest of them is treated by surgery, which includes excision biopsy mastectomy, simple mastectomy and MRM.68\% of benign breast lumps were treated conservatively.

Some of the cases subjected to cytological/histological diagnosis, most were Fibroadenoma and fibrocystic disease of breast, as was expected. $26 \%$ of breast lump presented with histologically proved malignancy.

In this study, sensitivity and specificity of clinical examination to detect malignancy was $87.5 \%$ and $95.6 \%$ respectively. Most of these women presented with large masses in the breast. The average size of presentation of malignant breast lump was $5.17 \times 4.38 \mathrm{cms}$. These masses were discovered accidentally and only a rare patient carried out regular self examination or underwent screening mammography. More than half of the patients with breast lump seek medical advice after 6 months. Previous studies have identified ignorance, fear and fatalistic attitude, socioeconomic conditions, traditional belief, low customs are important factors resulting in delay. ${ }^{25-29}$

The proportion of married women was $80.5 \%$. Only $2 \%$ had used birth control pills for contraception for duration of more than 1 year. Nineteen percent were nulliparous, $38 \%$ had borne $1-2$ children. $28 \%$ had $3-5$ children, and $15 \%$ had 6 children or more.

Ultrasound is recommended in all cases where there is a clinical suspicion of malignancy even if the mammogram is normal. Any focal mammography or ultrasound abnormality should undergo needle biopsy. Breast ultrasound does not expose the patient to ionizing radiation and with its relatively easy availability and cost effectiveness; it has already proven to be an important adjunct to the other radiological and pathological studies for the breast.

\section{Conclusion}

Ultrasound used liberally as an adjunct to mammography, increases the cancer detection rate by almost $15 \%$. It was found that HRUSG is more accurate in dense breast tissue, female $<35$ yrs of age \& mammography is more accurate in old ages, $>35$ yrs. Different studies have shown that the most common lesions are benign and needs proper diagnosis. Thus the FNAC smears have very high accuracy in diagnosis of breast lump. ${ }^{63,64}$ The FNAC of breast is cheap, safe and highly accurate preoperative method for diagnosis of breast lesions. But core needle biopsy is the diagnostic method of choice for malignant lumps. Preoperative categorization of breast lesions is utmost important for management of the patient. Increase of awareness, in general population, is the utmost important tool for early detection as wel as decrease in mortality \& morbidity of patients suffering from malignant breast disease.

\section{Declarations}

FUNDING: No funding source/grant was available. No external fund was available. All investigations and treatment were done free of cost in the government teaching hospital named BSMCH,WB,India.

Conflict of interest. The authors declare that they have no competing interests.

Ethical approval: Obtained from the Institutional Ethics Committee, BSMCH, Bankura, West Bengal, India. Approval letter (Memo No.BSMC/aca/219 dt 13.01.18) is available for review by the editor of the journal. Written consents from individual patients were also obtained. 


\section{References}

1. Alkabban FM, Ferguson T. Cancer, Breast. [Updated 2019 Jun 4]. In: StatPearls [Internet]. Treasure Island (FL): StatPearls Publishing; 2020 Jan-. Available from: https://www.ncbi.nlm.nih.gov/books/NBK482286/

2. Michael C. Perry. Breast Lump. In: Walker HK, Hall WD, Hurst JW, editors. Clinical methods: The history, physical, and laboratory examinations. $3^{\text {rd }}$ Boston: Butterworths; 1990. Chapter 170.

3. Bailey \& Love; Benign breast disease. Short practice of surgery. $27^{\text {th }}$ CRC; 2018 . Chapter 53.

4. Schmitt, S.J. Benign Breast Disease and breast cancer risk morphology and beyond. American Journal of Surgical pathology 2003; 27: 836-841

5. Hill D.A., Preston Martin S, Ross R.K and Bernstein L, Medical radiation, family history of cancer and Benign Breast Disease in relation to breast cancer risk in young women in U.S.A. Cancer causes control 2002; 13: 711-718.

6. Webb, P.M., C.Byrne, SJ Schmitt, J.L. Connolly. T. Jacobs, G. Piero, W. Willet and G.A C Colditz, Family history of breast cancer, age and benign breast disease. Int. J. Cancer 2002; 100: 375-378.

7. William H. Hindle, Payne PA, Pan EY. The use of fine needle aspiration in the evaluation of persistent palpable dominant breast masses. American Journal of Obstetrics and Gynaecology 1993; 168:1815-1819.

8. P Tan, Z M Azlan, M P Rumaisa, M R Siti Aisyah Murni, S Radhika, M I Nurismah, A Norlia, M A Zulfiqar; The comperative accuracy of ultrasound and mammography in the detection of breast cancer; Med J Malaysia 2014; 69(2): 79-85

9. K. Tiwari, Suvendu Ghosh, V K Agrawal, Diagnostic accuracy of mammography and ultrasonography in assessment of reast cancer; ijcmer 2017; vol 4: 81-83.

10. Ann L. Brown, Jordana Phillips, Pricilla J. Slanetz, V. F. Zachary, S. Vekataraman, V. Dialani, Tejas S. Mehta, Clinical value of mammography in the evaluation of palpable breast lumps in Women 30 years old and older; AJR 2017; 209(4): 935-942

11. Kolb TM, Lichy J. Newhouse JH Comparison of the performance of screening mammography, physical examination, and breast US and evaluation of factors that influence them: an analysis of 27,825 patient evaluations. Radiology. 2002, 225:165-75.)

12. Yang WT, Mok CO, King W. Tang A. Metreweli C.; Role of high frequency ultrasonography in the evaluation of palpable breast masses in Chinese women: alternative to mammography? J of Ultrasound in Med, 1996; 15(9): 637-644.

13. Dar-Ren Chen, Ruey-Feng Chang, Yu-Len Huang; breast cancer diagnosis using self-organizing map for soography; elsevier 2000; 26(3): 405-411

14. N Lingaraju, $P$ Narashimhaswamy, R Murali Mohan, $N$ Venkatesh; Evaluation of palpable breast lumps under the age of 35 years with triple assessment; Int J Sci Stud 2016; 4(1): 10-15

15. Abhijit Saha, Madhumita Mukhopadhyay, C. Das, K. Sarkar, A. Kumar Saha, D. KR Sarkar; FNAC versus Core needle biopsy: a comparative study in evaluation of palpable breast lump; JCDR 2016; 10(2): EC05-EC08

16. Giri, Efficacy of fine needle aspiration cytology in evaluation of breast lumps: A one year study; IJCRR 2013; 5(6): 114-118.

17. Ying- Hua, Wei Wei, Jian-Lun Liu; Diagnostic value of fine needle aspiration iopsy for reast mass: a systematic review and meta-analysis; BMC cancer 2012; 12(1): 41

18. Bettina H. Kamphausen, Thilo Toellner, Ilka Ruschenburg;The value of ultrasound-guided fine-needle aspiration cytology of the breast: 354 cases with histoligical correlation. Anticancer Res.2003;23(3C):3009-3013

19. Rebekah R. White, Terri J. Halperin, JohnA. Olson, Marry S. Soo, Rex C. Bentley, Hilliard F. Seigler; Impact of core-needle breast biopsy on the surgical management of mammographic abnormalities; Ann surg. 2001 Jun ; 233(6) : 769-777

20. Michael S. Ballo, Nour Sneige; Can core needle biopsy replace fine needle aspiration cytology in the diagnosis of palpable breast carcinoma: A comparative study of 124 women; ACS Journals 1996; 78(4): 773

21. S. Fattahi, Alireza Tavassoli, Mahmood Reza Kalantari, Sajad Noorshafiee, Majid Rahmanin. Evaluation of the value of core needle biopsy in the diagnosis of a breast mass. Archives of breast cancer 2016; 3(2): 56-61,

22. Smriti Hari, S. Kumari, A. Srivastava, S. Thulkar, S. Mathur, P. T. Veedu; Image guided versus palpation guided core needle iopsy of palpable breast masses: a prospective study; Indian J Med Res. 2016; 143(5): 597-604.

Page 9/10 
23. Khanna, S. Aryya, N.C.. Khanna, N.N: Spectrum of benign breast disease. Indian. J. Surg. 1988; 50: 169.

24. Rangabashyam, N., Gnanaprakasam, D., Krishnaraj, D.B., Monohar, V. Vijayalakshmi, S.R., Spectrum of benign breast lesions in Madras. J. Roy. Coll. Surg. (Edin.) 1983; 28:369,

25. Hackett TP. Cassem NH, Raker JW; Patient delay in cancer. N. Engl.J. Med., 1973; 289: 14-20.

26. Adams SA, Homer JK, Vessey MP. Delay in treatment for breast cancer. Community Med., 1980; 2:195-201.

27. Nichols S. Waters WE, Fraser JD, et al. Delay in the presentation of breast Symptoms for consultant investigation. Community Med.1981; 3:217-225.

28. Robinson E., Mohilever J., Borovick R.; Factors affecting delay in diagnosis of breast cancer: relationship of delay to stage of disease; Israeli, J. Med. Sei. 1986; 22:333-336.

29. Elzawawy A. M, Alaadeen M. E, SM Dawood, Hussaam M E, Atef Badran; Delay in seeking medical advice and late presentation of Female breast cancer patients in Most of the world. Could we make Changes? The experience of 23 years in Port Said, Egypt. Reast Care (Basel) 2008; 3(1): 37-41. 